\title{
HOMELESSNESS WITHIN SOCIAL CHANGE
}

\author{
Assis. Prof. Dr. Neşide Yıldırım \\ Sakarya University Faculty of Arts and Sciences Social Work Department \\ Esentepe Campus SAKARYA/TÜRKIYE \\ nyildirim@sakarya.edu.tr \\ Assis. Prof. Dr. Kazım Yıldırım \\ Sakarya University Esentepe Campus SAKARYA/TÜRKIYE \\ kyildirim@sakarya.edu.tr
}

DOI:10.5901/mjss.2014.v5n22p418

\begin{abstract}
Homelessness, which is a combination of so many social problems, is one of the important indicators of the tragedy of humanity nowadays. It has become a current social problem again because of some reasons such as urbanization, be refugee status as a result of wars, migrations because of unemployment and poverty, alcohol and drug addiction, mental illnesses, terrorism, domestic violence and natural disasters. Although there are different descriptions of homelessness it is generally the event which some people sustains their lives in public places, parks or streets because they have no shelter of their own. Homelessness is a prism that reflects especially the frustrations of housing, welfare, education, health services and the justice system. This complex social phenomenon opposed to the basic definitions and resists against easy solutions. Homeless are not just the people whose opportunities and options are limited by poverty, but also those who are restricted because of mental illness, drug abuse, physical and sexual violence, ignorance, complex medical problems and getting older. The aim of this research is to discuss the psychological, sociological and economic problems of people who do not have a place for their own to use as a shelter; and to compare the solutions and strategies of some countries for the prevention of homelessness. In the study we focused on identification of the phenomenon of homelessness, the reasons for homelessness and the general characteristics of the homeless people. The sample of study is a social worker working in Istanbul, Turkey Darülaceze (Hospice) Institution and eleven homeless staying there; a social worker working in the city of Kassel, Germany Soziale Hilfe e.V. Kassel Institution and eleven homeless staying there; eight social workers working in the city of Ljubljana, Slovenya Kralji Ulice Institution and eleven homeless staying there; and a social worker working in Shelter Institution. The data were collected using interview, questionnaire, survey techniques and observations were made where appropriate.
\end{abstract}

Key Words: Homelessness, Social Work, Darülaceze, Türkiye, Germany, Slovenia.

\section{HOMELESSNESS WITHIN SOCIAL CHANGE INTRODUCTION}

Homelessness has become a current social problem because of some reasons such as urbanization, industrialization, be refugee status as a result of wars, unemployment, migrations because of poverty, alcohol and drug addiction, mental illnesses, terrorism, domestic violence and natural disasters. It has increasingly reached a feared significant problem for all countries. Although seen throughout human history, homelessness has not been a living problem in the recent years.

There are 100 million homeless in the world according to the reports of the United Nations (The report on the homeless in Turkey, 2011). These are the people who do not have a place to stay in and live in the streets (parks, under stairs, in doorways, under bridges) or in refugee camps.

Homelessness was seen as a major problem especially in many European Union member countries and developed and industrialized countries of the world and social scientists have done some researches on this issue.

Aim of this study is to identify psychological, sociological and economic problems of individuals who do not have a place used as a shelter of their own or rented; to compare the services for homeless people in Turkey, Germany and Slovenia; and to provide recommendations for the prevention of homelessness. 
For this purpose, the questionnaire which was prepared inTurkish, English, German and Slovenian language has been applied to some homeless people living in Turkey, Germany and Slovenia. The questionnaire is limited to a total of 20 questions which eight are open-ended and 12 closed-ended. The data obtained in the survey are shown "findings and comments" section in the tables and comments have been made according to the results.

In this study, some of the non-governmental organizations related to homelessness located in Istanbul, which is the most populous city in Turkey, the city of Kassel ${ }^{1}$ in Germany and the capital city of Slovenia, Ljubljana ${ }^{2}$ were examined. The study is limited to ten social workers, thirty-three homeless, four institutions, three cities and three countries as total. A social worker working in the city of İstanbul, Turkey Darülaceze (Hospice) Institution and eleven homeless staying there; a social worker working in the city of Kassel, Germany Soziale Hilfe e.V. Kassel Institution and eleven homeless staying there; eight social workers working in the city of Ljubljana, Slovenia Kralji Ulice Institution and eleven homeless staying there; and a social worker working in Shelter Institution. The data were collected using interview and survey techniques and observations were made where appropriate.

\section{HOMELESSNESS}

Homelessness is the event which some people sustains their lives in public places because they have no shelter of their own. Drake et al (1982) has defined Homeless as "Every single person without his or her home". But Larew described homelessness as "the lack of suitable conditions for settlement and social marginalization," (Türkcan ve Türkcan, quoted from 1996). Under U.S.A. law, homeless is described as the people who do not have a house or a residence, living in the streets and avenues, no appropriate place to sleep at night; the ones who stay at hotels, housing estates, prisons and places for mentally ill that provide temporary living conditions; the ones living in social housing which are under control; the ones living in institutional settings, allowing for temporary housing. Homelessness is described as the status of the process of living such life style (Yağan, 2009). It is known that according to researches, since 1980s in the United States, more than 1.5 million people become to live on the streets, about 3 million people do not have a place to live for, and 13.5 million people living in this country are homeless at some time in their lives (Plumb, 1997).

Homelessness is a prism that reflects especially the frustrations of housing, welfare, education, health services and the justice system. This complex social phenomenon opposed to the basic definitions and resists against easy solutions. Homeless are not just the people whose opportunities and options are limited by poverty, but also those who are restricted because of mental illness, drug abuse, physical and sexual violence, ignorance, complex medical problems and advancing years. When the subject focuses on the studies are examined, it is emphasized that poverty is not the only reason for homelessness. Alcoholism, drug addiction and mental illness are the features which also seen in homeless people. Poverty and inflation, reduction in earning power and opportunities, economic downturn, industrialization and however resulting unemployment, lack of social security policies are defined the main reasons for homelessness (Baum ve Burness, 1993).

Homelessness, which is a serious social problem, has begun to be felt increasingly in Turkey too. Problems such as migrations from villages to cities, housing problem and unemployment have been caused to homelessness. Apart from these, problems such as rapid population growth of cities as a result of migration from villages to cities, unplanned urbanization, lack of appropriate infrastructure (basis/bases), divorces, lack of social security, low income, not to benefit from health services enough, inadequate and unbalanced nutrition, drug addiction constitute a significant social destruction for people. The number of unhealthy and problematic people has been multiplying, in parallel with this; the number of homeless people in the streets of big cities has rapidly been increasing day by day (Altun, 1997).

\subsection{Types of Homelessness}

Smith (2000), Illhan and Ergün (2010) made three types of classifications about homelessness. These are:

Episodic homelessness: The ones, who are likely to remain homeless from time to time, live below the poverty line and faced with the risk of becoming homeless constantly.

\footnotetext{
1 This section has been prepared basing on my student Selman Bölükbaşı's (Sakarya University, Faculty of Arts and Sciences, Department of Social Work) final assignment done in 2012 to which I served as a consultant and have directed to study on homeless. 2 This section has been prepared basing on my student Selman Bölükbaşı's (Sakarya University, Faculty of Arts and Sciences, Department of Social Work) final assignment done in 2012 to which I served as a consultant and have directed to study on homeless.
} 
Temporary homelessness: The ones whose homelessness is not a very long time. Unlike the homeless people, they describe themselves as a part of the society. Anxiety, depression symptoms, alcohol and substance abuse can be seen at this type of homeless. Their lifestyles are not accepted. They strive to regain their homes, jobs and social status.

Chronic homelessness: Kind of ongoing long-term or repeated homelessness. They accept to live on the streets as normal and clearly identified as homeless. They are very skeptical at communications with other individuals in the society.

\subsection{Reasons of Homelessness}

Homelessness, depending on industrialization and globalization, is one of the major social problems felt in every country in the world. There are several theories attempting to explain the causes of homelessness. These are: systematic reasons theory, personal inadequacy theory, victim model theory, aggrieved model theory.

According to the systematic reasons theory homelessness occurs as a result of inadequate or failed mental health policies, high unemployment rate and lack of opportunities such as inadequate housing. The theory of personal inadequacy accepts alcoholism, drug addiction, and mental illness, lack of social relations, not to take responsibility, laziness or free lifestyles as the causes of homelessness. While victim model theory describes homelessness as remaining of individuals helpless in difficult life conditions (Özdemir, 2010), aggrieved model theory describes as the lack of adequate social support and problem solving skills (Van, 1993).

Roth and Bean (1986) show the causes of homelessness in their studies as in the following:

Deinstitutionalization: The process of reducing a person's dependence on an institutional environment, the practice of moving people (especially those with developmental disability) from mental institutions into community-based or familybased environments. The releasing of institutionalized individuals from institutional care (as in a psychiatric hospital) so that to take care in the community.

Economic factors: Unemployment, poverty, lack of opportunities to obtain suitable housing, imbalances in the distribution of wages and so on.

Social issues: The parents, relatives and friends of homeless would not adapt to them or do not wish to adapt to them, marital problems, previously being lived in a variety of care institutions and so on.

\subsection{Shelters of Homeless: Health, Food and Drink and Clothing}

During the summer months, many of them stay at parks, gardens, walkways, park benches and streets. However, in the winter months, they will have to find indoor and sheltered places such as ATMs, under bridges, bus and train stations, abandoned houses to avoid themselves from cold and rain. They have been trying to protect themselves from the wind and rain using discarded cardboard boxes or old sponges as beds most of the time.

Generally, they continue their lives with the money and food given by public and the shopkeepers. Some of them eat food collected from the garbage. They wear old clothes. They can not figure out health problems because they have no money and social security. When they are ill, they either wait for self-healing or wait for the suffering end. Due to cold, hunger and inadequate sanitation they face to all kinds of diseases.

\section{RESULTS AND COMMENTS}

The questionnaire about the homeless in Turkey, Germany and Slovenia was prepared in Turkish, English, German and Slovenian languages. It is limited to a total of 20 questions which 8 of them are open-ended and 12 closed-ended. The data obtained as a result of questionnaire is shown in the following tables.

According to the data Table 1, the highest homelessness rate in Turkey is $45,5 \%$ between the ages $18-30$. The same rate in Slovenia is between the age 31-44, and the highest homelessness rate in Germany is $54,5 \%$ between the ages $45-59$. When these results are examined it is remarkable that while development levels of countries increases the age group of homelessness goes up too.

The age group between 18-59 homelessness is more in total homelessness. The reasons are the ones who are under 18 can stay in foster homes (orphanage) and the ones who are over 60 can stay in the old people's home and elderly care centers, but there are no special places for accomodation for the ones who are between 18-60 ages.

According to some researches, more than half of the homeless people are men, but according to some researches done in recent years it has shown that the numbers of homeless women are more than men. It is understood that this situation 
is related to domestic violence and one third of homeless women left their home because of they faced to abuse and they become homeless (Yağan, 2009).

Analyzing the data of Table 2, the distribution of homelessness according to sex it is seen that the proportion of men $(78.8 \%)$ is more than women. Furthermore, when every country is compared among them it is understood that the homeless rate of men is almost the same but the homeless men in the homeless population are more than women. In my opinion the reason of this can be explained by women can easily find a place for accomodation than men and the number of woman shelter houses are more than man shelter houses.

According to the data of Table 3 it is understood that the rate of unmarried is at the first place and most of the homeless are unmarried. There is no relation between the development level of countries and maritial status. It can be said that not having a continuous housing has affected the maritial status of homeless and made it difficult to have a relationship with the gender.

Considering the number of homeless children in Table 4, it is understood that a large proportion of homeless people, such as $66.7 \%$ have no children. And the ones with children only have one or two. In the study, there is no significant relationship between the number of children and the development level of the countries.

Considering the general level of education of homeless people in total (Table 5), it is understood that, $15.2 \%$ not have any education, $39.4 \%$ graduated from primary school, $24.2 \%$ graduated from secondary school, $12.1 \%$ graduated from high school and $9.1 \%$ graduated from colleges or universities. Although the data show that most of the homeless are graduated from primary school, at the same time the data reveals the fact that higher education graduates might be homeless too.

When the countries compared on the basis of homelessness and education; it is understood that in Turkey the level of education increases, the rate of homelessness has decreased (Table 5). In Germany, the absence of homeless without education whereas people who have higher education are homeless is noteworthy. In Slovenia, there is proximity to each level of education the proportion of people who are homeless.

As it is shown in Table 6; $12.1 \%$ of homeless people's parents are alive and the mother and father were married, $18.2 \%$ of their mothers are alive, $6.1 \%$ of their fathers are alive. $42.4 \%$ of their parents died, and $21.2 \%$ of thier both mother and fathers are alive, but live separately. According to this result, it is understood that the vast majority of homeless people's (42.4\%) mothers and fathers are not alive. This result should be seen as the basic indicator of the family which serves a protector duty in society. It is likely to be homeless when taking any moral and material support from the family. However, in the case of if the father is still alive being homeless rate is low compared to the mother is still alive. This should be regarded as a sign of father who is seen as a source of income in the family and who provides the necessary economic support of the child.

One of the applicants in Slovenia stated being his cause of homelessness as his mother chuck out him of the house. In the EU countries, families cut subsidies due to economic and personal independence of children after 18 years, so this situation can be among the reasons for the high number of homeless in these countries. In Turkey, where the traditional structure is dominated, the children (daughters or sons) are separated from their parents after marrying or starting a business. Even they continue to get the support from their parents lifelong.

According to Table 7, $54.5 \%$ of homeless people live alone and $27.3 \%$ of homeless people live with friend(s). These two rates are higher than the others and show that homeless prefer to live alone or with close friends and colleagues environment.

When we compare the data by countries, it is seen that as the countries developed, the proportion of homeless people living alone is increasing. In Germany it is seen the highest level. In Turkey homeless people prefer to live with friends and groups.

When we examine how many of those who participated in the study were homeless at what age (Table 8), it is understood that the highest frame rate is $39.4 \%$, with the age group of 18-30; and the other rates are close to each other $(15.2 \% 0-17 ; 18.2 \%$ of $31-44 ; 21.2 \% 45-59 ; 6.1 \%$ of 60 or over 60 years old). This shows homelessness starts at any age.

There has not been established any relationship between the development level of countries and homelessness. It is seen that in all three countries, homelessness starts since the age of 18 . Another feature of the homeless people is it is their choice to live on the streets. A large part of these people refuse to enter an institution and live under the rules and regulations. It is indicated that homelessness has a cyclic structure; the majority of homeless people left the prevention (housing) system within two years after they are included the system (Karamustafalıoğlu, 2007). 
As shown in Table 9 when asked how long they were homeless, according to the study the average 12.8 months in Turkey, Slovenia, 22.7 months and 38.1 months in Germany. The average of the countries is 24.5 months.

According to these data, Turkey is below the overall average, Slovenia is close to the overall average and Germany is above the overall average. So, it can be said that there is a direct correlation between time of being homeless and the development level of countries.

While long-term homelessness is common in Germany, temporary and short-term homelessness is mentioned in Turkey. In the period the questionary was applied it was encountered that there was culture of homelessness in Germany and some of the applicants have stated that it was their own choices to be homeless. It is possible to show this situation among the long-term causes of homelessness.

According to the data in Table 10, 39.4\% of the homelesses never exposed to oppression and violence, but $36.4 \%$ of them exposed to psychological, and $24.2 \%$ of them exposed to physical oppression and violence. None of the homeless in the survey mentioned that they were exposed to other types of domestic violence or oppression.

In Turkey and Slovenia, while physical pressure and violence leave its place to psychological pressure and violence; in Germany, being more advanced country, physical violence and repression surpassed the psychological pressure and violence. According to the interview results identified, in Slovenia, it was understood that the homeless people were humiliated as the form of "Why do you not work, find a job? Why do you lazy around, dirty guys? Do we have to feed you?" as psychological pressure and violence. The homeless in Turkey stated that they exposed to physical oppression and violence from the thinner addicted individuals.

According to the data Table11, it is understood that $39.4 \%$ of the homeless benefited from non-governmental organization or any charity organisations; $21.2 \%$ of them benefited from the state and state institutions and agencies, $21.2 \%$ of them benefited from religious institutions and organizations; $12.1 \%$ of them benefited from other sources.

When these data were evaluated according to the countries, it is understood that in Turkey, the homeless benefited from religious institutions and agencies are in majority (54.5\%), while rate receiving assistance from the state is $9.1 \%$. In Slovenia, religious institutions and organizations left their places to civil society organizations and charities (54.5\%). In Germany, individuals are both benefited from non-governmental organizations and charities as well as government and state institutions in the same proportions (45.5\%) and supported by aid. Thus, it is understood that Germany provides more powerful support to the homeless compared to other countries which constitute the sample.

When the data in the Table 12 are examined, it is understood that $78.8 \%$ of homeless people always smoke; $6.1 \%$ of them occasionally smoke; $15.2 \%$ of them are non-smokers. Accordingly, it can be said that the vast majority of homeless people are smokers; there is no significant relationship between the country's development level and homelesness-smoking rate.

According to the data Table 13, when "yes" and "occasionally" items taken together, it is understood that the rates of homeless who use and not use alcohol is close to each other. When we compare the countries, it is noted that the "occasionally" ratio is equal in Turkey and Slovenia. In Germany the rate of alcohol use of homeless people is less than expected, because beer can be accepted as a traditional beverage and not a sprit. In Turkey, a "yes" can not expressed because drunken people are not welcome to stay or shelter in the state-owned or private institutions.

Information obtained from open-ended questions of the questionary can be briefly summarized as follows according to the countries:

\section{Turkey:}

Reasons of homelessness: Earthquake, unemployment, migration, economic, terror, war and conflict.

Result of homelessness: Negative impact on social welfare and community communication, abstraction of individuals themselves from society.

Social security: Most of them have no health insurance; a few of them have green cards.

Health problems: Common cold, pneumonia, cancer.

Whose decision to be homelessness: According to most of them it is not their decision, but they are homeless due to unavoidable reasons.

Demands: They want the state to increase business opportunities and support its citizens. 
Advices: Strengthening of social guarantees, to provide home and job opportunities to the poors, to treate patients.

Germany:

Reasons of homelessness: Loss of housing, unemployment, statelessness, economic, freedom, disease and war against capitalism.

Results of homelessness: It does not affect social welfare and social communication

Social security: Almost all of them have health insurance, and most of them Krankenkasse and AOK'1.

Health problems: A few of them are tuberculosis.

Whose decision to be homelessness: According to most of them it is not their decision; they are homeless because of reasons mentioned above; there are individuals who indicates that to be homeless is their decision, those who say they live such a life to lead away from the imperialist world set the culture of homelessness and there are people who have adopted the culture of homelessness.

Demands: More social housing.

Advices: Fight against the homelessness and capitalism

Slovenia:

Reasons of homelessness: The biggest factor is drug addiction, then expel from the family, later immigration, economy and unemployment.

Results of homelessness: Negative impact on social welfare and communication with the community or society.

Social security: Partial health insurance as required by the State.

Health problems: Drug addiction.

Whose decision to be homelessness: Inevitably reasons.

Demands: They want the Government to make more homes and ease of construction policies.

Advices: Never use of addictible drugs.

\section{CONCLUSIONS AND RECOMMENDATIONS}

It is understood that, the services offered and the studies conducted on homelessness, which has become one of the increasing social problems in recent years, differ according to the societies. In this study it is found out that the phenomenon of homelessness is not seen as an important problem in Turkey, so the social services and assistance offered by the state for homeless people is not continuous, and the aids made mostly through charitable people and religious organizations $(54.5 \%)$. This situation reveals the need for non-governmental organizations in Turkey. On contrast, in Germany, the ones who get aids from the state/government agencies and organizations (45.5\%) is higher according to the non-governmental organization or charitable institutions. In Slovenia, the number of those who get aids from non-governmental organizations or charities (54.5\%) are higher than the others.

It is understood that when the development levels of countries increases, the age of being homelessness increases too. In general, it is found out that the rate of homeless according to gender, men; according to marital status, singles; according to the number of children, people without children were more than. Almost half of the homeless people's parents (42.4\%) are dead and more than half (54.5\%) of homeless live alone. This situation emphasizes how necessary for human to live under the roof of a family being as a social creature and in need of nursing care (See Tables).

Although the majority of homeless people had low educational level, there are also homeless people who had higher education. There is a direct relation between the development level of countries and duration of being homeless. While the vast majority of homeless people (78.8\%) are smoking, the habit of using alcohol is not as high as the same ratio.

As a result, when the state's organizations are not enough in these areas it will be beneficial to the welfare of society to provide service to all kinds of people in need by increasing the number of non-governmental organizations, charitable associations and foundations. Especially in Turkey, it is recommended that governorships and municipalities, particularly

\footnotetext{
1 Local Public Health Insurance Funds
} 
in large cities, should establish houses, residences and social institutions which give permanent services to homeless people and citizens; the state should provide economic support to persons that establish such institutions; in these institutions, homeless people's all kinds of needs - material and spiritual- care, treatment and rehabilitation should be provided by the relevant staff; phone service should be provided so that to report the people living on the streets to the authorized persons and organizations; inter-agency cooperation should work in coordination with each other; the donations and benfits which given by the charitable organizations and religious institutions should spread throughout the year; some activities and vocational training should be done for the suitable persons to have a profession.

Briefly, the following can be said about these three countries: The homeless people do not have economic power to provide services to meet their basic needs and self-care. Staying on the streets for a long time and the negativity of living conditions lead to various health problems on these persons (such as schizophrenia, arthritis, pneumonia, drug addiction, etc.). These people living on the streets are faced to all kinds of social danger and risks. Their lives are put at risk by the mafia of organs and gangs of beggars. Therefore, many institutions and disciplines should cooperate with each other when creating services for homeless people. For this purpose, it must be performed that shelter, care and basic needs of homeless people should be provided; health problems should be eliminated; by making home calls, the ones who have family should be ensured to return to their family; and the ones who have no family should be placed into a permanent organization where they can take care and rehabilitation services.

\section{REFERENCES}

ALTUN, Gürcan (1997), 1991-1995 Yılları Arasında İstanbul'da Görülen Evsiz İnsan Ölümleri, Uzmanlık Tezi, Trakya Üniversitesi, Tıp Fakültesi, Adli Tıp Anabilim Dalı, Edirne.

BAUM, S. ve W., BURNES (1993), A National in DenialTheTruthAboutHomelessness, Westview Pres, San Francisco. BÖLÜKBAŞI, Selman (2012), Evsizlik ve Sosyal Hizmet (Almanya, Slovenya Ve Türkiye Örneği). Bitirme Ödevi. Sakarya Üniversitesi, Fen Edebiyat Fakültesi Sosyal Hizmet Bölümü.

ILHAN, Nesrin ve Ayşe ERGÜN (2010), "Evsizler ve Toplum Sağlığı", Eğitim-Kültür ve Araştırma Dergisi, İstanbul.

KARAMUSTAFALIOĞLU, KO. Bakım, B. Güveli, M. Özçelik, B. Uzun, UE (2007), "İstanbul'daki evsizlerde psikiyatrik bozukluklar", Düşünen Adam: Psikiyatri ve Nörolojik Bilimler Dergisi, İstanbul.

KOSEC, Boris (t.y.), ShelterfortheHomeless in Ljubljana, Presentation of theProgramme, Ljubljana.

ÖZDEMiR, Uğur (2010), "Evsizlik ve Evsizlere Genel bir Bakış”, Toplum ve Sosyal Hizmet, Cilt: 21, Sayı: 2, Ankara.

PLUMB, JD. (1997), Homelessness: Care, Prevention, andPublicPolicy, http://www.ncbi.nlm.nih.gov/pubmed/9182475, e.t: 08.04.2012.

ROTH D. ve GJ. Bean (1986), "New Perspectives on Homelessness: Findingsfrom a StatewideEpidemiologicalStudy", HospitalandCommunityPsychiatry.

SMITH, C M. (2000), CommunityHealthNursingTheoryandPractice (2rd Ed.), W B. SaundersCompany.

TÜRKCAN Solmaz ve Ahmet TÜRKCAN (1996), "Psikiyatri ve Evsizlik Bir Gözden Geçirme Çalışması", Düşünen Adam, İstanbul.

TÜRKIYE'DE EVSIZLERE DAIR RAPOR (2011), Durum Tespiti, Avrupa Birliği Ülkelerinden Uygulama Örnekleri ve Taleplerimiz.

VAN, R. (1993), HomelessnessFamilies: Causes, EffectsandRecommendations, Garland Publishing, New York. YAĞAN, Murat (2009), Ankara'da Evsiz Ölümleri, Uzmanlık Tezi, Gazi Üniversitesi, Tıp Fakültesi, Adli Tıp Anabilim Dalı, Ankara.

(http://www.darulaceze.gov.tr e.t:23.06.2014).

\section{TABLES}


Table 1: Distribution of Age and Country

\begin{tabular}{|c|c|c|c|c|c|}
\hline \multirow[t]{2}{*}{ Age } & & \multicolumn{3}{|l|}{ Country } & \multirow[b]{2}{*}{ Total } \\
\hline & & Turkey & Slovenia & Germany & \\
\hline \multirow[t]{2}{*}{$0-17$} & Number & 1 & 0 & 0 & 1 \\
\hline & $\%$ & $9,1 \%$ & $0 \%$ & $0 \%$ & $3,0 \%$ \\
\hline \multirow[t]{2}{*}{$18-30$} & Number & 5 & 3 & 1 & 9 \\
\hline & $\%$ & $45,5 \%$ & $27,3 \%$ & $9,1 \%$ & $27,3 \%$ \\
\hline \multirow[t]{2}{*}{$31-44$} & Number & 2 & 5 & 2 & 9 \\
\hline & $\%$ & $18,2 \%$ & $45,5 \%$ & $18,2 \%$ & $27,3 \%$ \\
\hline \multirow[t]{2}{*}{$45-59$} & Number & 2 & 2 & 6 & 10 \\
\hline & $\%$ & $18,2 \%$ & $18,2 \%$ & $54,5 \%$ & $30,3 \%$ \\
\hline \multirow[t]{2}{*}{$60+$} & Number & 1 & 1 & 2 & 4 \\
\hline & $\%$ & $9,1 \%$ & $9,1 \%$ & $18,2 \%$ & $12,1 \%$ \\
\hline \multirow[t]{2}{*}{ Total } & Number & 11 & 11 & 11 & 33 \\
\hline & $\%$ & $100,0 \%$ & $100,0 \%$ & $100,0 \%$ & $100,0 \%$ \\
\hline
\end{tabular}

Table 2: Gender

\begin{tabular}{|c|c|c|c|c|c|}
\hline \multirow[t]{2}{*}{ Gender } & & \multicolumn{3}{|l|}{ Country } & \multirow[b]{2}{*}{ Total } \\
\hline & & Turkey & Slovenia & Germany & \\
\hline \multirow[t]{2}{*}{ Woman } & Number & 2 & 2 & 3 & 7 \\
\hline & $\%$ & $18,2 \%$ & $18,2 \%$ & $27,3 \%$ & $21,2 \%$ \\
\hline \multirow[t]{2}{*}{ Man } & Number & 9 & 9 & 8 & 26 \\
\hline & $\%$ & $81,8 \%$ & $81,8 \%$ & $72,7 \%$ & $78,8 \%$ \\
\hline \multirow[t]{2}{*}{ Total } & Number & 11 & 11 & 11 & 33 \\
\hline & $\%$ & $100,0 \%$ & $100,0 \%$ & $100,0 \%$ & $100,0 \%$ \\
\hline
\end{tabular}

Table 3: Maritial Status 


\begin{tabular}{|c|c|c|c|c|c|c|}
\hline & \multicolumn{2}{|l|}{ Maritial status } & \multicolumn{3}{|l|}{ Country } & \multirow[b]{2}{*}{ Total } \\
\hline & & & Turkey & Slovenia & Germany & \\
\hline \multirow{2}{*}{\multicolumn{2}{|c|}{ Single }} & Number & 8 & 6 & 7 & 21 \\
\hline & & $\%$ & $72,7 \%$ & $54,5 \%$ & $63,6 \%$ & $63,6 \%$ \\
\hline \multirow{2}{*}{\multicolumn{2}{|c|}{ Have partner }} & Number & 2 & 2 & 3 & 7 \\
\hline & & $\%$ & $18,2 \%$ & $18,2 \%$ & $27,3 \%$ & $21,2 \%$ \\
\hline \multirow{2}{*}{\multicolumn{2}{|c|}{ Married }} & Number & 0 & 1 & 0 & 1 \\
\hline & & $\%$ &, $0 \%$ & $9,1 \%$ &, $0 \%$ & $3,0 \%$ \\
\hline \multirow{2}{*}{\multicolumn{2}{|c|}{ Seperated }} & Number & 1 & 2 & 1 & 4 \\
\hline & & $\%$ & $9,1 \%$ & $18,2 \%$ & $9,1 \%$ & $12,1 \%$ \\
\hline \multirow[t]{2}{*}{ Total } & & Number & 11 & 11 & 11 & 33 \\
\hline & & $\%$ & $100,0 \%$ & $100,0 \%$ & $100,0 \%$ & $100,0 \%$ \\
\hline
\end{tabular}

Table 4: Number of Child

\begin{tabular}{|c|c|c|c|c|c|c|}
\hline & \multicolumn{2}{|c|}{ Number of } & \multicolumn{3}{|l|}{ Country } & \multirow[b]{2}{*}{ Total } \\
\hline & & & Turkey & Slovenia & Germany & \\
\hline & \multirow[t]{2}{*}{0} & Number & 10 & 5 & 7 & 22 \\
\hline & & $\%$ & $90,9 \%$ & $45,5 \%$ & $63,6 \%$ & $66,7 \%$ \\
\hline & \multirow[t]{2}{*}{1} & Number & 0 & 3 & 1 & 4 \\
\hline & & $\%$ &, $0 \%$ & $27,3 \%$ & $9,1 \%$ & $12,1 \%$ \\
\hline & \multirow[t]{2}{*}{2} & Number & 1 & 2 & 0 & 3 \\
\hline & & $\%$ & $9,1 \%$ & $18,2 \%$ &, $0 \%$ & $9,1 \%$ \\
\hline & \multirow[t]{2}{*}{3} & Number & 0 & 0 & 2 & 2 \\
\hline & & $\%$ &, $0 \%$ &, $0 \%$ & $18,2 \%$ & $6,1 \%$ \\
\hline & \multirow[t]{2}{*}{4} & Number & 0 & 0 & 1 & 1 \\
\hline & & $\%$ &, $0 \%$ &, $0 \%$ & $9,1 \%$ & $3,0 \%$ \\
\hline & \multirow[t]{2}{*}{5} & Number & 0 & 1 & 0 & 1 \\
\hline & & $\%$ &, $0 \%$ & $9,1 \%$ &, $0 \%$ & $3,0 \%$ \\
\hline \multirow[t]{2}{*}{ Total } & & Number & 11 & 11 & 11 & 33 \\
\hline & & $\%$ & $100,0 \%$ & $100,0 \%$ & $100,0 \%$ & $100,0 \%$ \\
\hline
\end{tabular}


Table 5: Status of Education

\begin{tabular}{|c|c|c|c|c|c|}
\hline \multirow[t]{2}{*}{ Status of Education } & & \multicolumn{3}{|l|}{ Country } & \multirow[b]{2}{*}{ Total } \\
\hline & & Turkey & Slovenia & Germany & \\
\hline İlleterate & $\begin{array}{l}\text { Number } \\
\%\end{array}$ & $\begin{array}{l}3 \\
27,3 \%\end{array}$ & $\begin{array}{l}2 \\
18,2 \%\end{array}$ & $\begin{array}{l}0 \\
, 0 \%\end{array}$ & $\begin{array}{l}5 \\
15,2 \%\end{array}$ \\
\hline Primary & $\begin{array}{l}\text { Number } \\
\%\end{array}$ & $\begin{array}{l}3 \\
27,3 \%\end{array}$ & $\begin{array}{l}4 \\
36,4 \%\end{array}$ & $\begin{array}{l}6 \\
54,5 \%\end{array}$ & $\begin{array}{l}13 \\
39,4 \%\end{array}$ \\
\hline Secondary & $\begin{array}{l}\text { Number } \\
\%\end{array}$ & $\begin{array}{l}3 \\
27,3 \%\end{array}$ & $\begin{array}{l}2 \\
18,2 \%\end{array}$ & $\begin{array}{l}3 \\
27,3 \%\end{array}$ & $\begin{array}{l}84,2 \% \\
24 \%\end{array}$ \\
\hline High school & $\begin{array}{l}\text { Number } \\
\%\end{array}$ & $\begin{array}{l}2 \\
18,2 \%\end{array}$ & $\begin{array}{l}1 \\
9,1 \%\end{array}$ & $\begin{array}{l}1 \\
9,1 \%\end{array}$ & $\begin{array}{l}4 \\
12,1 \%\end{array}$ \\
\hline University & $\begin{array}{l}\text { Number } \\
\%\end{array}$ & $\begin{array}{l}0 \\
, 0 \%\end{array}$ & $\begin{array}{l}2 \\
18,2 \%\end{array}$ & $\begin{array}{l}1 \\
9,1 \%\end{array}$ & $\begin{array}{l}3 \\
9,1 \%\end{array}$ \\
\hline Total & $\begin{array}{l}\text { Number } \\
\%\end{array}$ & $\begin{array}{l}11 \\
100,0 \%\end{array}$ & $\begin{array}{l}11 \\
100,0 \%\end{array}$ & $\begin{array}{l}11 \\
100,0 \%\end{array}$ & $\begin{array}{l}33 \\
100,0 \%\end{array}$ \\
\hline
\end{tabular}

Table 6: Status of Parents

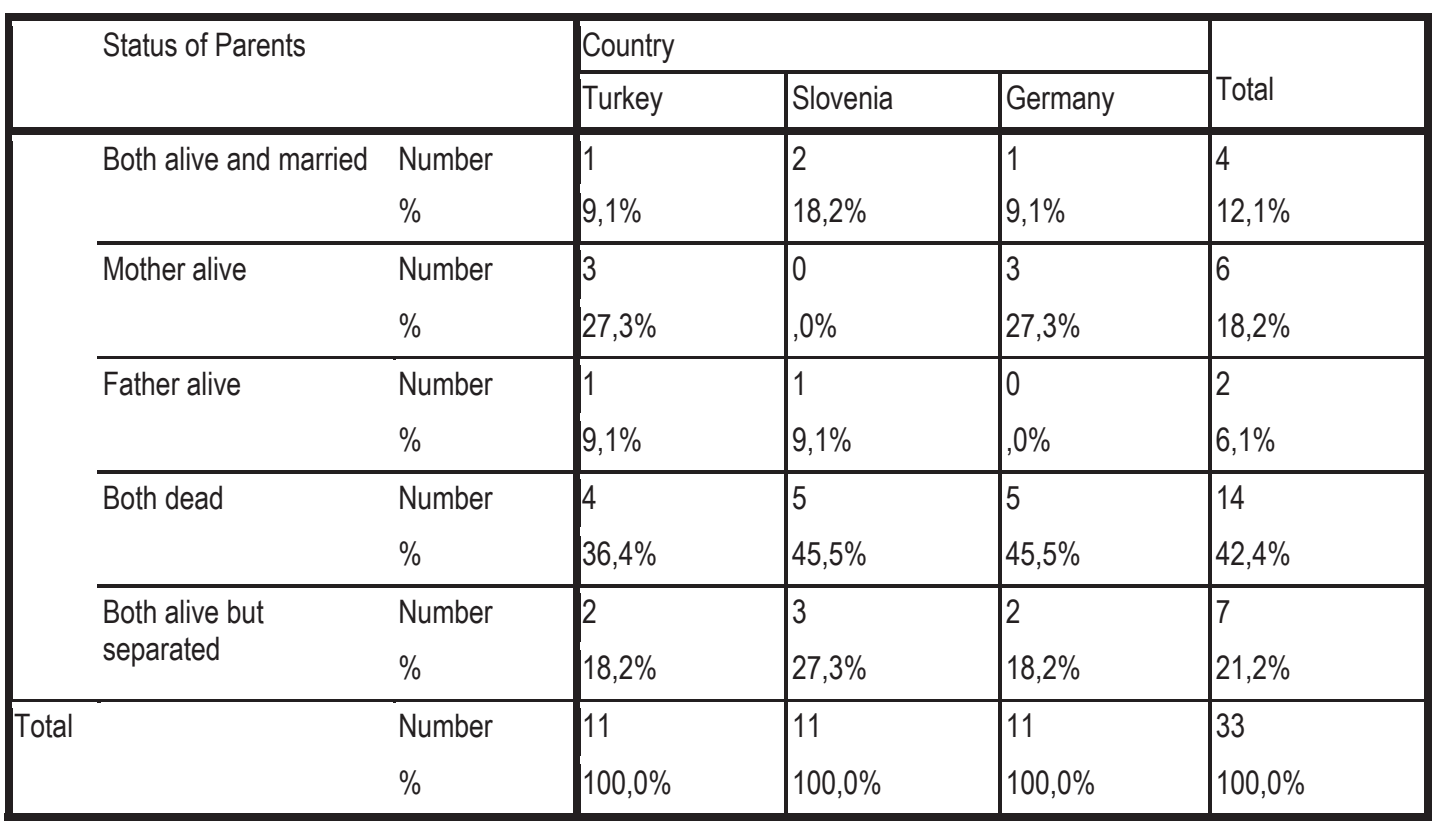


Table 7: Life Styles

\begin{tabular}{|c|c|c|c|c|c|}
\hline \multirow[t]{2}{*}{ Life style } & & \multicolumn{3}{|l|}{ Country } & \multirow{2}{*}{ Total } \\
\hline & & Turkey & Slovenia & Germany & \\
\hline Alone & $\begin{array}{l}\text { Number } \\
\%\end{array}$ & $\begin{array}{l}4 \\
36,4 \%\end{array}$ & $\begin{array}{l}6 \\
54,5 \%\end{array}$ & $\begin{array}{l}8 \\
72,7 \%\end{array}$ & $\begin{array}{l}18 \\
54,5 \%\end{array}$ \\
\hline With friend/s & $\begin{array}{l}\text { Number } \\
\%\end{array}$ & $\begin{array}{l}6 \\
54,5 \%\end{array}$ & $\begin{array}{l}1 \\
9,1 \%\end{array}$ & $\begin{array}{l}2 \\
18,2 \%\end{array}$ & $\begin{array}{l}9 \\
27,3 \%\end{array}$ \\
\hline With mother and/or father & $\begin{array}{l}\text { Number } \\
\%\end{array}$ & $\begin{array}{l}0 \\
0 \%\end{array}$ & $\begin{array}{l}1 \\
9,1 \%\end{array}$ & $\begin{array}{l}0 \\
, 0 \%\end{array}$ & $\begin{array}{l}1 \\
3,0 \%\end{array}$ \\
\hline With spouse & $\begin{array}{l}\text { Number } \\
\%\end{array}$ & $\begin{array}{l}0 \\
0 \%\end{array}$ & $\begin{array}{l}2 \\
18,2 \%\end{array}$ & $\begin{array}{l}0 \\
0 \%\end{array}$ & $\begin{array}{l}2 \\
6,1 \%\end{array}$ \\
\hline With boy/girl friend & $\begin{array}{l}\text { Number } \\
\%\end{array}$ & $\begin{array}{l}1 \\
9,1 \%\end{array}$ & $\begin{array}{l}0 \\
, 0 \%\end{array}$ & $\begin{array}{l}1 \\
9,1 \%\end{array}$ & $\begin{array}{l}2 \\
6,1 \%\end{array}$ \\
\hline Other & $\begin{array}{l}\text { Number } \\
\%\end{array}$ & $\begin{array}{l}0 \\
.0 \%\end{array}$ & $\begin{array}{l}1 \\
9,1 \%\end{array}$ & 0 & $\begin{array}{l}1 \\
3,0 \%\end{array}$ \\
\hline Total & $\begin{array}{l}\text { Number } \\
\%\end{array}$ & $\begin{array}{l}11 \\
100,0 \%\end{array}$ & $\begin{array}{l}11 \\
100,0 \%\end{array}$ & $\begin{array}{l}11 \\
100,0 \%\end{array}$ & $\begin{array}{l}33 \\
100,0 \%\end{array}$ \\
\hline
\end{tabular}

\begin{tabular}{|c|c|c|c|c|c|c|}
\hline \multirow[t]{2}{*}{ Table 8: } & \multicolumn{2}{|c|}{ Homelessness } & \multicolumn{3}{|l|}{ Country } & \multirow[b]{2}{*}{ Total } \\
\hline & & & Turkey & Slovenia & Germany & \\
\hline & \multirow[t]{2}{*}{$0-17$} & Number & 3 & 1 & 1 & 5 \\
\hline & & $\%$ & $27,3 \%$ & $9,1 \%$ & $9,1 \%$ & $15,2 \%$ \\
\hline & \multirow[t]{2}{*}{$18-30$} & Number & 4 & 6 & 3 & 13 \\
\hline & & $\%$ & $36,4 \%$ & $54,5 \%$ & $27,3 \%$ & $39,4 \%$ \\
\hline & \multirow[t]{2}{*}{$31-44$} & Number & 1 & 3 & 2 & 6 \\
\hline & & $\%$ & $9,1 \%$ & $27,3 \%$ & $18,2 \%$ & $18,2 \%$ \\
\hline & \multirow[t]{2}{*}{$45-59$} & Number & 2 & 1 & 4 & 7 \\
\hline & & $\%$ & $18,2 \%$ & $9,1 \%$ & $36,4 \%$ & $21,2 \%$ \\
\hline & \multirow[t]{2}{*}{$60+$} & Number & 1 & 0 & 1 & 2 \\
\hline & & $\%$ & $9,1 \%$ &, $0 \%$ & $9,1 \%$ & $6,1 \%$ \\
\hline \multirow[t]{2}{*}{ Toplam } & & Number & 11 & 11 & 11 & 33 \\
\hline & & $\%$ & $100,0 \%$ & $100,0 \%$ & $100,0 \%$ & $100,0 \%$ \\
\hline
\end{tabular}


Table 9: How Long They Have Homeless (Monthly)

\begin{tabular}{|l|l|l|l|l|}
\hline \multicolumn{2}{|l|}{ Duration } & \multicolumn{2}{l|}{ Country } & \multirow{2}{*}{ Average } \\
\cline { 2 - 5 } & Turkey & Slovenia & Germany & \\
\hline Month & 12.8 & 22.7 & 38.1 & 24.5 \\
\hline
\end{tabular}

Table 10: What Kind of Pressure and Violence They Encounter From Outside

\begin{tabular}{|c|c|c|c|c|c|c|}
\hline & \multirow[t]{2}{*}{$\begin{array}{l}\text { Pressure and } \\
\text { violence }\end{array}$} & & \multicolumn{3}{|l|}{ Country } & \multirow{2}{*}{ Total } \\
\hline & & & Turkey & Slovenia & Germany & \\
\hline & No & $\begin{array}{l}\text { Number } \\
\%\end{array}$ & $\begin{array}{l}2 \\
18,2 \%\end{array}$ & $\begin{array}{l}3 \\
27,3 \%\end{array}$ & $\begin{array}{l}8 \\
72,7 \%\end{array}$ & $\begin{array}{l}13 \\
39,4 \%\end{array}$ \\
\hline & Physical & $\begin{array}{l}\text { Number } \\
\%\end{array}$ & $\begin{array}{l}4 \\
36,4 \% \\
\end{array}$ & $\begin{array}{l}2 \\
18,2 \% \\
\end{array}$ & $\begin{array}{l}2 \\
18,2 \%\end{array}$ & $\begin{array}{l}8 \\
24,2 \% \\
\end{array}$ \\
\hline & Psychological & $\begin{array}{l}\text { Number } \\
\%\end{array}$ & $\begin{array}{l}5 \\
45,5 \%\end{array}$ & $\begin{array}{l}6 \\
54,5 \%\end{array}$ & $9,1 \%$ & $\mid \begin{array}{l}12 \\
36,4 \%\end{array}$ \\
\hline Total & & $\begin{array}{l}\text { Number } \\
\%\end{array}$ & $\begin{array}{l}11 \\
100,0 \%\end{array}$ & $\begin{array}{l}11 \\
100,0 \%\end{array}$ & $\begin{array}{l}11 \\
100,0 \%\end{array}$ & $\begin{array}{l}33 \\
100,0 \%\end{array}$ \\
\hline
\end{tabular}

Table 11: Resources and Help Places

\begin{tabular}{|c|c|c|c|c|c|c|}
\hline & \multicolumn{2}{|l|}{ Resources and Help Places } & \multicolumn{3}{|l|}{ Country } & \multirow[b]{2}{*}{ Total } \\
\hline & & & Turkey & Slovenia & Germany & \\
\hline & $\begin{array}{l}\text { State/Foundations belong to } \\
\text { state }\end{array}$ & $\begin{array}{l}\text { Number } \\
\%\end{array}$ & $\begin{array}{l}1 \\
9,1 \%\end{array}$ & $\begin{array}{l}1 \\
9,1 \%\end{array}$ & $\begin{array}{l}5 \\
45,5 \%\end{array}$ & $\mid \begin{array}{l}7 \\
21,2 \%\end{array}$ \\
\hline & NGO & $\begin{array}{l}\text { Number } \\
\%\end{array}$ & $\begin{array}{l}2 \\
18,2 \%\end{array}$ & $\begin{array}{l}6 \\
54,5 \%\end{array}$ & $\begin{array}{l}5 \\
45,5 \%\end{array}$ & $\begin{array}{l}13 \\
39,4 \%\end{array}$ \\
\hline & Religious foundations & $\begin{array}{l}\text { Number } \\
\%\end{array}$ & $\begin{array}{l}6 \\
54,5 \%\end{array}$ & $\begin{array}{l}1 \\
9,1 \%\end{array}$ & $\begin{array}{l}0 \\
, 0 \%\end{array}$ & $\begin{array}{l}7 \\
21,2 \%\end{array}$ \\
\hline & Red Crescent/ Red Cross & $\begin{array}{l}\text { Number } \\
\%\end{array}$ & $\begin{array}{l}0 \\
, 0 \%\end{array}$ & $\begin{array}{l}1 \\
9,1 \%\end{array}$ & $\begin{array}{l}0 \\
, 0 \%\end{array}$ & $\begin{array}{l}1 \\
3,0 \%\end{array}$ \\
\hline & Family and relatives & $\begin{array}{l}\text { Number } \\
\%\end{array}$ & $\begin{array}{l}0 \\
, 0 \%\end{array}$ & $\begin{array}{l}1 \\
9,1 \%\end{array}$ & $\begin{array}{l}0 \\
, 0 \%\end{array}$ & $\begin{array}{l}1 \\
3,0 \%\end{array}$ \\
\hline & Other & $\begin{array}{l}\text { Number } \\
\%\end{array}$ & $\begin{array}{l}2 \\
18,2 \%\end{array}$ & $\begin{array}{l}1 \\
9,1 \%\end{array}$ & $\begin{array}{l}1 \\
9,1 \%\end{array}$ & $\begin{array}{l}4 \\
12,1 \%\end{array}$ \\
\hline Tota & & $\begin{array}{l}\text { Number } \\
\%\end{array}$ & $\begin{array}{l}11 \\
100,0 \%\end{array}$ & $\begin{array}{l}11 \\
100,0 \%\end{array}$ & $\begin{array}{l}11 \\
100,0 \%\end{array}$ & $\begin{array}{l}33 \\
100,0 \%\end{array}$ \\
\hline
\end{tabular}


Table 12: Smoking Rates

\begin{tabular}{|c|c|c|c|c|c|c|}
\hline & Smoking & & Country & & & \\
\hline & & & Turkey & Slovenia & Germany & Total \\
\hline & Yes & $\begin{array}{l}\text { Number } \\
\%\end{array}$ & $\begin{array}{l}7 \\
63,6 \%\end{array}$ & $\begin{array}{l}11 \\
100,0 \%\end{array}$ & $\begin{array}{l}8 \\
72,7 \%\end{array}$ & $\begin{array}{l}26 \\
78,8 \%\end{array}$ \\
\hline & Sometimes & $\begin{array}{l}\text { Number } \\
\%\end{array}$ & $\begin{array}{l}1 \\
9,1 \%\end{array}$ & $\begin{array}{l}0 \\
, 0 \%\end{array}$ & $\begin{array}{l}1 \\
9,1 \%\end{array}$ & $\begin{array}{l}2 \\
6,1 \%\end{array}$ \\
\hline & No & $\begin{array}{l}\text { Number } \\
\%\end{array}$ & $\begin{array}{l}3 \\
27,3 \%\end{array}$ & $\begin{array}{l}0 \\
, 0 \%\end{array}$ & $\begin{array}{l}2 \\
18,2 \%\end{array}$ & $\begin{array}{l}5 \\
15,2 \%\end{array}$ \\
\hline Total & & $\begin{array}{l}\text { Number } \\
\%\end{array}$ & $\begin{array}{l}11 \\
100,0 \%\end{array}$ & $\begin{array}{l}11 \\
100,0 \%\end{array}$ & $\begin{array}{l}11 \\
100,0 \%\end{array}$ & $\begin{array}{l}33 \\
100,0 \%\end{array}$ \\
\hline
\end{tabular}

Table 13: Rates of Alcohol Use

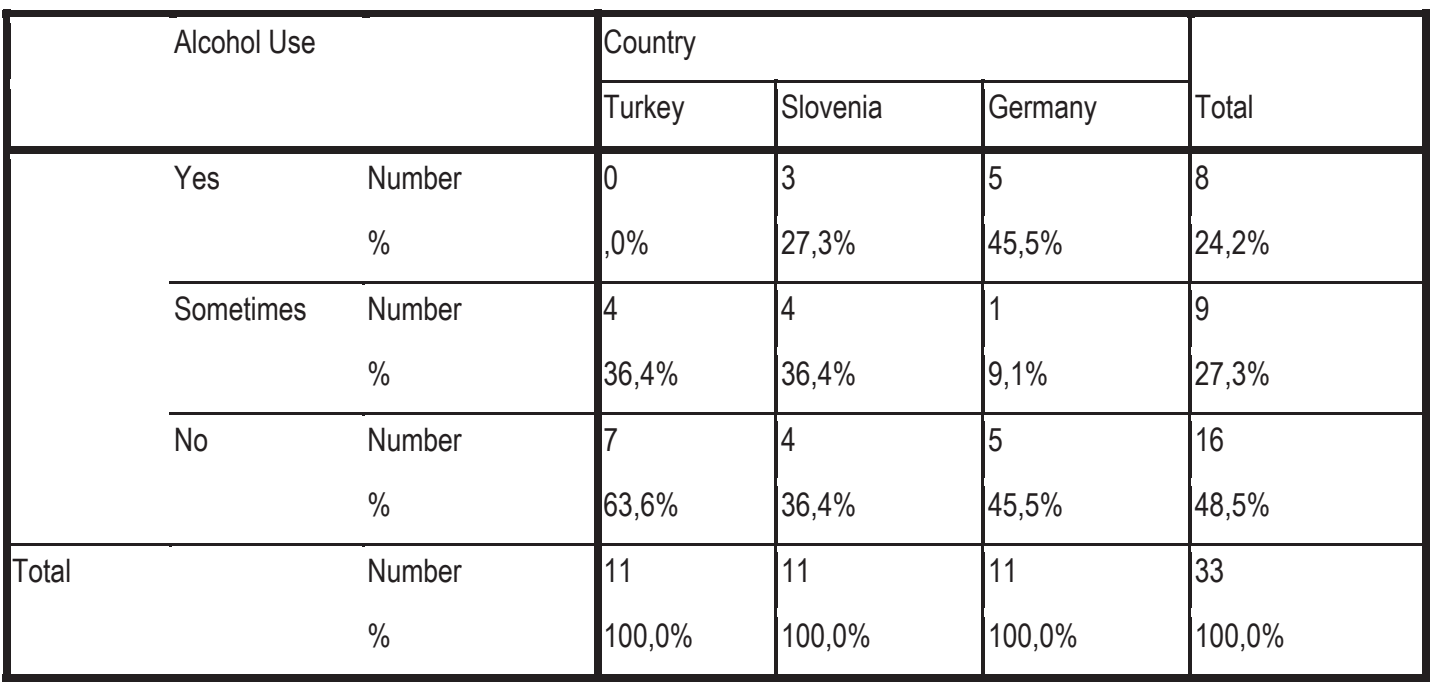

\section{APPENDIXES}

Darülaceze (Hospice) is the oldest institution serving in İstanbul. It was built in 1896 and put into service Sultan Abdülhamit II's (1842-1918) request to gather beggars, unaccompanied children loitering in the streets, lonely people lying in the courtyard of a mosque and diseased people who lived in İstanbul and to make them the chastening of art and in order to have homeless people end their lives in peace.

The purpose of Darülaceze is to serve those who have born and settled in İstanbul, and those who are disabled and incapable for work, those who have no facilities to ensure the amount of gain, and disabled, infirm and elderly people over 18 years old who have no one legally obliged to take care of themselves in İstanbul or in the provinces, and those who have been found on the streets, and underprivileged children in the 0-3 age group and the children under protection. 
Hospice which is a compassion home has been serving people regardless of religion, language, race, class and gender differences. Here, all the needs of shelter residents such as clothing, shelter, food, health and care are covered by the institution and the service continues 24 hours a day. Residents' physical examination and treatment services, preventive health services and acute or chronic illness have being treated, in the situations that require further examination and treatment any medical treatment is implemented by establishing links with hospitals. The places of worship of the monotheist religions mosque, church and synagogue are in a combination in the yard of the Hospice that does not exist any country in the world.

These are the service units located within the institution;

Child Care: It is a unit where 0-3 age group street deserted children's all kinds of needs are met (housing, food, clothing, health care).

Semi-Adequate Male Department: It is a unit where all kinds of needs of male residents who partially remedied their daily living activities are met.

Self-sufficient Male Department: It is a unit where all kinds of needs of male residents who can perform their daily living activities without assistance are met.

Bedridden Women's Office: It is a unit where all kinds of needs of female residents who are bed-bounded and do not fulfill all kinds of activities of daily living shelter, food, clothing, health care) are met.

Self-sufficient Female Department: It is a unit where all kinds of needs of female residents who can perform their daily living activities without assistance are met. It has 96 bed capacities (http://www.darulaceze.gov.tr e.t.:23.06.2014).

Although there are many non-governmental organizations carrying out studies on homeless, the Soziale Hilfe e.V. Kassel we examined as an example in this research has been established on small scale assistance such as aid and housing in 1885. Many voluntary organizations, supporters and sponsors are mobilized support the work of the organization and to improve the status of the city's poorest people. In recent years, it draws attention that the number of young people who want aids has been increasing and the highest rate of them is young women. The actual financing of the organization is covered by Hessen State Administration and the European Social Fund.

The following activities are carried out today in the center of Soziale Hilfe:

Night Mansions: The social services which are provided for homeless not subjected to cold in winter. In cold weather, the accommodation of homeless people at nights is provided with mobile flats or homes.

Panama-Day Accommodation: It is a place where the homeless who have economic and personal problems come to rest and to take counseling/advice. It gains importance especially during the cold seasons. The services offered here include: Lunch is $€ 1.25$, while fruits and tea are free of charge. Toilet, shower and bath services; clothing and finery; washing and drying; the health service, luggage room; financial management; various entertainment and cultural educational activities such as newspapers, magazines, and internet; crafts, games and sports activities; social counseling; help for homeless and former prisoners.

Among 4 Wall - Life Women: It is designed for homeless women. The women who are living in unsafe housing, do not have a fixed place at least for two months, released from prison may be substituted for guest houses. The aim is to provide a safe shelter and social issues to develop a personal perspective for women.

Eastern Panama - Regional Office: It helps those who live in Bettenhausen and gives services such as breakfast, counseling, support and leisure.

Kassel Prison Counseling: Every day from 14:00 to 16:00, counseling services are given by social workers for those who are in prison and want consulting.

For Foreigners: It is the assistance provided to special case of foreign prisoners by Hessen State Government.

Studies in Public Places Support Presentations and Street: It is the support which is provided with local authority for homeless people.

Kralji Ulice, which was founded in the capital Ljubljana and continues to serve in an active way today, is the sample of this research. Kralji Ulice, which means "King of the streets" in Turkish, is a non-governmental organization provides services for the homeless.

The beginning story of the Kralji Ulice is described as follows: In December 2004, Professor. Dr. Razpotnik Špela and a group of social pedagogy students decide to spend 24 hours on the streets with homeless people in a cold winter day. During the time they spend together, the people live on the streets help them. Practitioners saw that the people living on the streets are as not as terrible personality as they appear. In the following days they gather various aids to help people who are homeless and make necessary arrangements with organizations. In May 2005, the first number (sayı) of the first Slovenian Street Magazin (Street Papers $/$ Straßenmagazin) related to social subjects with homelessness printed and sold by homeless people. Kralji Ulice charity was established by the homeless in September 2005. In July 2006, Newspaper Distribution and the editorial Center of Kralj Ulice started to give service at Poljanska Cesta 14. In October 2009, it moved to its present location the Prazakova 6. In the Institution, some activities and services such 
as book reading, information retrieval, talk to social workers and volunteers, keeping their belongings, using computer and internet, eating and drinking something are given for the homeless. In 2008, the Norway model is applied as a pilot project and apartments for the homeless were rented to live in one and a half years. By 2011, there were 5 apartments with this project and 18 people living in Ljubljana.

The following activities are constantly organized at this institution:

Street Broadcast Magazine: The number of 62 published until July 2011 and sales reached 10.000 each month.

Street Magazine Sales and Distribution: There have been 300 sellers so far. 80 people sell monthly. Sellers buy a magazine for $€ 0.50$ and sell $€ 1$ on the street.

Under the Stars College: It is a kind of open education planned with limited facilities for individuals who are socially excluded. At this training some activities are carried out such as social organizations, cultural and educational workshops, theater, video, music, language, and computer and so on.

Field Work and Social Work: Healthy vehicles for safe use of drugs and syringes are provided at field works. Within the social works; counseling, monitoring, parity and communication services are provided for homeless people who stay on the streets, unsafe housing, shelters and other institutions and organizations such as hospitals, prisons and so on.

Volunteer Working: A tutorial basic education and social services are given for future social workers. In addition, the opportunity to work as a volunteer with homeless people is offered to students who study in faculty of education and social services.

Empowerment of People Deprived of Social Rights: It is a kind of information point. It comprises the services such as social assistance, consulting, internet and telephone usage, hot drinks and light meals, second-hand clothes, money storage, donation distribution and so on.

Shelter is a special part of the program for the Centre of Social Services in the center of Ljubljana. It is the first shelter for the homeless in Slovenia and the model was the starting point for a network of similar programs throughout the country. There are five staffs; a social worker and four volunteer and another five professional staffs work at the part of the container. Although $86 \%$ of financial instruments have come from the city and the other countries, the rest of the tools are provided by donors for users. This institution offers low possibility programs for the survival of people living on the streets. With the efforts of volunteers new conditions have been created for the users to benefit actively from here. People who use containers as shelter were collected in three groups (Kosec, n.d):

Shelter-Residence: It is a program that provides social support and functionality. It provides social services such as accommodation, food, clothing and footwear, maintenance of hygiene for 24-hour. It is reserved for homeless people residing in the community of Ljubljana for the last time. Users from the other communities can provide accommodation only under special conditions. Shelter can not be completely filled in order to help people in need in case of emergency.

Food Distribution: Hot meal is given once in a day. Food distribution is done by approximately 100 people. During visits, if the homeless want, they can be laundered. It is open for the homeless from 11:00 to 13:00 every day and until 15:00 peak days. The highest rate who benefited from the distribution of food is the retired people. However, the other users are young people, alcohol and drug addicts. Most of people who benefited from service have social problems as well as psychic disorders.

Shelter for the night: the program has become operational since 2005. The only requirement to use the service and to be accepted to the shelters is to obey the rules respectfully. 